International Journal of Instruction e-ISSN: 1308-1470 • www.e-iji.net

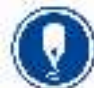

July $2021 \bullet$ Vol.14, No.3

p-ISSN: 1694-609X

pp. 133-152

Article submission code: 20200815093110

Received: $15 / 08 / 2020$

Revision: 01/12/2020
Accepted: 24/12/2020

OnlineFirst:17/04/2021

\title{
Improving Critical Thinking Skills of Geography Students with Spatial- Problem Based Learning (SPBL)
}

\section{Waode Yunia Silviariza}

Student, Faculty of Social Sciences, State University of Malang, Indonesia, waode.yunia.2007219@students.um.ac.id

\section{Sumarmi}

Prof., Faculty of Social Sciences, State University of Malang, Indonesia, sumarmi.fis@um.ac.id

\section{Budi Handoyo}

Dr., Faculty of Social Sciences, State University of Malang, Indonesia,

budi.handoyo.fis@um.ac.id

\begin{abstract}
The 21st century demands that geography students think critically about orientation processes and analyze problems from a spatial perspective. This experiment presents data on how much influence the SPBL model has on critical thinking students of geography. The learning procedure carried out by students is oriented towards spatial problems, then formulates spatial problems, then collects and compiles data/information, then analyzes, discusses the results, ends with building communication. 78 students of the Department of Geography, State University of Malang were the subjects of this study. The critical thinking indicator from Ennis becomes the basis for making test questions for data collection. The use of the Independent sample t-Test with SPSS 23 for data analysis purposes. Based on the research results, it was seen that there was an increase in students' critical thinking after learning with the SPBL model. As many as 25\% of students were able to think very critically. However, based on the Gain-Score calculation, it shows effectiveness $<40 \%$. Thus, it becomes a recommendation for teachers to apply relevant learning models so that students are more critical and active in the geography learning process. Another suggestion for designers is to further evaluate the effectiveness of the SPBL model so that the quality of this product is better and can have a more significant impact.
\end{abstract}

Keywords: spatial-problem based learning, critical thinking skill, geography, learning, students

\section{INTRODUCTION}

A spatial perspective is a perspective that can be used to view and then solve geographic problems. In its approach, Geography provides an opportunity to study problems from a

Citation: Silviariza, W. Y., Sumarmi., \& Handoyo, B. (2021). Improving Critical Thinking Skills of Geography Students with Spatial Problem Based Learning (SPBL). International Journal of Instruction, 14(3),133-152. https://doi.org/10.29333/iji.2021.1438a 
spatial perspective (Yunus, 2008). Therefore, learning by recognizing and solving it with a spatial approach and analysis studying the problem, and looking at the problem from a spatial perspective is characteristic of true geography learning (Chun, 2010; Bednarz \& Bednarz, 2008).

Geography learning in the 21st century must direct students to look at problems and solve them from a geographical perspective, one of which is spatial (Nagel, 2008). Therefore, learning guidelines are important to support students to be active and critical in seeing and solving problems as well as being communicative by the 21st Century Geography education objectives.

Human resources in the 21 st century are important to have critical thinking skills (Snyder \& Snyder, 2008; Alismail, \& McGuire, 2015; Sumarmi, 2017; AlJaafi \& Şahin, 2019; Affandy, et al., 2019). Thus, the target of teachers in this century is important to prepare graduates who can think critically. Students who can think critically can face challenges in the future (Tsui, 2002; Ennis, 2011). Life and career readiness require critical thinking skills (Kraisuth \& Panjakajornsak, 2017). Even employers look for individuals who are not only capable of reading and writing but also capable of critical thinking (Casner-Lotto, \& Barrington, 2006; Sulaiman et al., 2008).

The 2010 survey notes reported that the 21st-century business world needs human resources with critical thinking skills (AMA, 2010). Other contemporary evidence shows that critical thinking is of utmost importance, according to 144 entrepreneurs surveyed (NACE, 2016). One of the ASEAN countries, in Thailand Vision 4.0, establishes critical thinking as a key pillar in the development of a new knowledgebased economy (Jones \& Pimdee, 2017).

Every individual needs to have critical thinking skills. Student learning conditions are often with a learning approach that is limited to discussing the material in books and tends to be not factual (Elbow \& Sharma, 2000). This is another challenge for teachers to encourage students to think critically (Karakoç, 2016). Therefore, an educator must think a lot in facilitating a class by choosing the latest models and methods that are more effective in directing and facilitating students to think critically.

Making the right decision is an indication that students think critically. Critical thinking must involve students in researching, differentiating, and evaluating information and reflection related to data and information to make judgments and convey decisions (Papathanasiou et al., 2014; Snyder \& Snyder, 2008). The critical thinking process trains students to make decisions with scientific steps.

Most students in Indonesia lack 21st-century skills. Several reports prove that Indonesian students are still classified as low in critical thinking (Wayudi, et al., 2019; Susilowati, et al., 2017; Suardana \& Selamet, 2017). Therefore, teachers and students need learning guidelines that facilitate the learning atmosphere to be critical.

The learning model is a guideline and framework that can support learning (Sumarmi, 2012). SPBL is one of them. The uniqueness of SPBL is that it provides opportunities 
for geography students to study a problem actively and scientifically and solve it with a spatial approach (Silviariza \& Handoyo, 2020).

SPBL with problem-solving characteristics with a spatial approach has the advantage to be applied to develop 21st-century skills. These advantages are: (1) students work in teams (Sun, et al., 2018), (2) With scientific observations and activities allow students to identify and formulate spatial problems (Darmaji, et al., 2019), (3) students think critically about contextual and factual spatial problems that want to achieve meaningful learning (Koohang et al., Nd; Loveless et al., 2006; Swan, 2005; Utami et al., 2016), (4) students can describe the relationship between one phenomenon with another (Nursa'ban, et al, 2020), (5) with scientific activities that allow students to practice making decisions from these spatial problems (Pérez - delHoyo, et al, 2020). With the application of SPBL, it is very appropriate to provide scientific Geography learning, hone teamwork skills, sensitivity, and critical decision making for students. Based on these descriptions, the researcher formulated two hypotheses as follows: "a class that applies the SPBL model during the learning process gets a higher critical thinking score than a class that does not". The purpose of this study is to produce information that the SPBL model affects improving students' critical thinking in higher education.

\section{Literature Review}

\section{SPBL as a Model of Teaching}

SPBL is created from integrating Problem Based Learning (PBL) with the same spatial geographic perspective as Spatial Based Learning (SBL) (Silviariza \& Handoyo, 2020). The integration between the SBL model which focuses on students' way of thinking about space and the PBL model which focuses on problem-solving makes SPBL a problem-solving-based Geography learning model with a geographical perspective with a spatial approach (Silviariza \& Handoyo, 2020). The implementation of the SPBL model aims to create an atmosphere of learning geography that is scientific, active, critical, creative, collaborative, and innovative in solving Geography problems (Silviariza, et al, 2020). Thus, the application of SPBL in geography classes can familiarize students with critical thinking to solve problems with a spatial approach.

This is motivated because in learning geography it is very important to solve problems critically (Nagel, 2008). Geography learning is a multidisciplinary science that contains complex and authentic spatial problems that allow students to solve problems critically (Huang et al., 2012). Thus, the application of SPBL in Geography subjects can influence critical thinking activities in solving geographic problems with a spatial approach. Furthermore, the table below describes the activities of each step in the SPBL model. 
Table 1

Step design for the SPBL learning model

\begin{tabular}{cll}
\hline No & \multicolumn{1}{c}{ Syntax } & \multicolumn{1}{c}{ Activity } \\
\hline 1 & $\begin{array}{l}\text { Orienting Spatial } \\
\text { problem }\end{array}$ & $\begin{array}{l}\text { Students scrutinize directly the spatial phenomena in the field. The teacher } \\
\text { becomes a facilitator by providing opportunities for students to recognize } \\
\text { space with the initial step of knowing its absolute and relative locations, } \\
\text { then looking at its spatial characteristics (cultural, social, and even } \\
\text { economic if needed), and recognizing the factors associated with that space. } \\
\text { The orientation of the problem in space is also done with related spatial } \\
\text { maps. This makes it easier for teachers and students to recognize objects } \\
\text { spatially. Non-forcefully, this activity allows students to think from a spatial } \\
\text { perspective }\end{array}$ \\
& $\begin{array}{l}\text { Formulating spatial } \\
\text { problems }\end{array}$ & $\begin{array}{l}\text { The activity of formulating spatial problems begins with student activities } \\
\text { in identifying the relationship between space and spatial phenomena }\end{array}$ \\
\hline 3 & $\begin{array}{l}\text { Collecting and } \\
\text { organizing spatial } \\
\text { data and } \\
\text { information }\end{array}$ & $\begin{array}{l}\text { For data and information from data collection results to be neatly organized } \\
\text { and easy to read, students make tables, graphs, diagrams }\end{array}$ \\
\hline 4 & $\begin{array}{l}\text { Analyzing spatial } \\
\text { data and discussing } \\
\text { the results }\end{array}$ & $\begin{array}{l}\text { After organizing and processing the data, students analyzed and discussed it } \\
\text { with their respective groups. Students analyze spatially with various spatial } \\
\text { analysis techniques that are following the characteristics and objectives of } \\
\text { the data. In analyzing the data that has been collected, students can use data } \\
\text { processing applications even if they need a Geographical Information } \\
\text { System (GIS), SPSS is also suggested. }\end{array}$ \\
& $\begin{array}{l}\text { In addition to building good communication skills, at this stage students are } \\
\text { welcome to present their arguments by the data and group discussions with } \\
\text { other groups. }\end{array}$ \\
\hline 5 & $\begin{array}{l}\text { Building } \\
\text { communication }\end{array}$ &
\end{tabular}

Source: (Silviariza \& Handoyo, 2020)

The SPBL model has five steps. The steps for the SPBL Geography learning model are as follows (Silviariza \& Handoyo, 2020); (1) orientate spatial problems, (2) formulate spatial problems, (3) collect, organize spatial data and information, (4) analyze spatial data, (5) build communication.

\section{The concept of Critical Thinking Skill}

The demands of the 21 st century are challenging humans as individuals and even groups to think critically in seeing and solving problems (Lai, 2011; Higgins, 2014; Snyder \& Snyder, 2008; Wagner, 2010; P21, 2015; Kereluik, 2013). Critical thinking is a skill that goes beyond memorization (Kraisuth \& Panjakajornsak, 2017; Haridza \& Irving, 2017). The world of work requires human resources who have skills other than basic knowledge (NACE, 2016; Sulaiman et al., 2008; Tapper, 2004) in problem-solving (Conklin, 2012).

Sharing their opinions, listening to other people's opinions, summarizing concepts with analysis, confirming and/or defending their opinions, making decisions, and solving problems in the real world are the characteristics of critical students (Nelson, 2013; ŽivkoviL, 2016; Karakoç, 2016). Students must behave intellectually and in a constellation that allows the person to be accustomed to thinking critically (Kereluik, 2013). One must improve critical thinking skills from school (Facione, 2011). Students 
must be accustomed to asking, interpreting, synthesizing, and digesting (Paul \& Elder, 2019).

Critical thinking activities are a student thinking process starting with asking questions (Nappi, 2017), examination (Yanchar, \& Slife, 2004), analysis (Saputra, et al, 2019), testing (Fatmawati, et al, 2019), and exploration (Rahmat, et al. al. al., 2020). Therefore, students need to recheck the scientific truth of each reason and gather facts from each side to think critically. Students become critical if they meet the indicators of critical thinking (Facione, 2000). Critical thinking indicators from Ennis (2011) become the benchmark for this study. The following provides indicators of critical thinking related to the syntax of the SPBL model (table 2).

Table 2

Indicators of students' critical thinking skills

\begin{tabular}{cll}
\hline No & \multicolumn{1}{c}{ Critical Thinking Skills } & \multicolumn{1}{c}{ Indicator } \\
\hline 1 & Formulation of The Problem & $\begin{array}{l}\text { Formulation of problems and provide directions to obtain } \\
\text { answers }\end{array}$ \\
\hline 2 & Giving Arguments & Providing arguments accompanied by suggestions \\
\hline 3 & Doing Deduction & Providing an explanation from general to specific \\
\hline 4 & Doing Induction & Making conclusions about the problem \\
\hline 5 & Evaluating & Evaluation based on facts \\
\hline 6 & Deciding and Implementing & $\begin{array}{l}\text { Determination and selection of alternative solutions to } \\
\text { problems for planning and implementation }\end{array}$ \\
\hline
\end{tabular}

Source: (Ennis, 2011)

Train students' critical thinking skills as well by using learning strategies. Constructing categorization, finding problems, and improving the environment are important strategies to encourage students to think critically (Facione, 2000). This strategy has the same goals as the SPBL syntax.

Table 3

The relevance of SPBL with strategies and indicators of critical

\begin{tabular}{llll}
\hline NO & \multicolumn{1}{c}{ SPBL steps } & \multicolumn{1}{c}{ Strategy } & \multicolumn{1}{c}{ Indicator of Critical Thinking } \\
\hline 1 & Spatial problem orientation & Building Categories & Giving Arguments \\
\hline 2 & Formulating spatial problems & Finding Problem & Formulating the Problem \\
\hline 3 & $\begin{array}{l}\text { Collecting and organizing } \\
\text { spatial data and information }\end{array}$ & Enhancing Environment & Giving Arguments \\
\cline { 4 - 4 } & & & Conducting Induction and Deduction \\
\cline { 4 - 4 } & & Enhancing Environment & Conducting Induction and Deduction \\
\cline { 3 - 4 } & & & Giving Arguments \\
\cline { 3 - 4 } & discussing the results & Evaluating \\
\hline 5 & Building Communication & Enhancing Environment & Giving Arguments \\
\cline { 3 - 4 } & & & Conducting Induction and Deduction \\
\cline { 3 - 4 } & & & Evaluating \\
\cline { 3 - 4 } & & & Deciding and Implementing \\
\hline
\end{tabular}

Source: (Facione, 2000; Silviariza \& Handoyo, 2020)

International Journal of Instruction, July $2021 \bullet$ Vol.14, No.3 
Thus, the application of SPBL is relevant with the aim of improving students' critical thinking.

\section{METHOD}

\section{Research Design}

Quasi-experimental with a pre-posttest control group is the design of this study. Figure 1 below is an illustration of how the experiment was carried out.

\begin{tabular}{llll}
\hline Experiment & $\mathrm{O} 1$ & $\mathrm{X}$ & $\mathrm{O} 2$ \\
\hline Control & $\mathrm{O} 3$ & - & $\mathrm{O} 4$ \\
\hline
\end{tabular}

Figure 1

The quasi-experimental procedure was adapted from Fraenkel et al. (2011)

\section{Subject}

Based on practical reasons, conditions, and ethics in the quasi-experimental sample design is not selective (Campbell \& Stanley, 2015; Fraenkel et al., 2011). The use of a purposive sampling technique to obtain samples that have the same characteristics of critical thinking skills. Another thing also shows that each class has the same ability; no class is superior. besides, taught by the same lecturer in the same subjects. Thus, the selection of class "K" as an experiment and class "A" as a control.

Experimental research was conducted in the 2018 Geography Education study program, State University of Malang (UM) in two different classes. Experimental research subjects were selected in the "Environmental Geography" class. The objectives of the "Environmental Geography" class; (1) examining the human environment; (2) critical human; (3) creative humans in protecting the environment; (4) people who actively protect the environment. These objectives are appropriate when implementing the SPBL model.

\section{Instruments and Procedures}

The purpose of testing the validity and reliability is to ensure that the instrument is good at measuring symptoms and produces valid data (Purwanto, 2009). 30 students who had taken the "environmental geography" course were top targets for the instrument test (validity and reliability). This means that the subject has learned how to recognize environmental problems and solve these problems.

At the beginning of the class meeting, students worked on the pretest questions. This aims to determine the initial abilities of students. Furthermore, the treatment uses the SPBL model. Furthermore, data collection from the final test to the experimental and control groups. The next step, data collection posttest results of the two subject groups. The data shows the critical thinking skills of control and experimental students before and after treatment with the SPBL model. The pre and post-test score calculation use the following equation (Purwanto, 2009). 


\section{$\boldsymbol{n}=\frac{\sum \mathrm{B}}{\mathrm{smi}} \mathbf{x} \boldsymbol{n} \max$}

Description:

$\mathrm{n}$ : final score

$\sum$ B: total correct (a grade that can be achieved by students)

smi: Highest score ideal (32)

n max: the highest score used (100).

Five questions related to environmental problems to measure whether students can think critically or not. The test questions are arranged based on indicators of critical thinking (Ennis, 2011). To answer these questions, the teacher provides students with spatial contextual questions from newspaper articles. Following are the item validation qualifications.

Table 4

Qualification of Item validation

\begin{tabular}{ll}
\hline Correlation coefficient & Qualification \\
\hline $0.800-1.000$ & Highly Valid \\
\hline $0.600-0.799$ & Valid \\
\hline $0.400-0.599$ & Valid enough \\
\hline $0.200-0.400$ & Less valid \\
\hline $0.000-0.199$ & Invalid \\
\hline
\end{tabular}

Source: (Purwanto, 2012)

The 5\% significance level becomes the basis for the analysis of the validity test using a two-sided test $(\alpha) .444$. Furthermore, the critical thinking skills test was declared valid based on the social material classification criteria. The results of statistical calculations for each item with sig. (2-tailed) $\leq 0.444$. In addition to validity, the measurement of instrument reliability is as follows.

\section{Table 5}

Item reliability criteria

\begin{tabular}{ll}
\hline Reliability value & Criteria \\
\hline $0.00-0.20$ & Very low \\
\hline $0.21-0.40$ & Low \\
\hline $0.41-0.60$ & Average \\
\hline $0.61-0.80$ & High \\
\hline $0.81-1.00$ & Very High \\
\hline Source: (Arikunto, 2010)
\end{tabular}

Source: (Arikunto, 2010)

The summary table presenting the results based on the reliability test is as follows. 
Table 6

Item reliability criteria

\begin{tabular}{|c|c|c|}
\hline Question No & Validity & Reliability \\
\hline $1 \mathrm{a}$ & 0.526 & \multirow{7}{*}{0.707} \\
\hline $1 b$ & 0.495 & \\
\hline 2 & 0.510 & \\
\hline 3 & 0.611 & \\
\hline $4 a$ & 0.447 & \\
\hline $4 \mathrm{~b}$ & 0.887 & \\
\hline 5 & 0.798 & \\
\hline
\end{tabular}

From the table above, we can conclude that the instruments used to collect valid and reliable data on critical thinking skills.

\section{Data Analysis}

Proof of improving students' critical thinking by testing the hypothesis. Hypothesis testing with SPSS 23 for windows uses the Independent sample t-test.

Table 7

Criteria for critical thinking skills

\begin{tabular}{lll}
\hline Classification & Score & Qualification \\
\hline A & $81-100$ & Highly critical \\
\hline B & $66-80$ & Critical \\
\hline C & $56-65$ & Critical enough \\
\hline D & $41-55$ & Less critical \\
\hline E & $0-40$ & Not critical \\
\hline
\end{tabular}

Table 7 indicates a significance level of 0.05 applies to decision making with the t-test (Purwanto, 2012).

\section{FINDINGS}

\section{Prerequisite Testing}

Proof of sample data is normally distributed or not by normality testing. It is normally distributed if most of it is close to average. SPSS with a 95\% Komlogoror Smirnov Test helps in normality testing. Summary of test results according to the following table.

Table 8

Normality Tets

\begin{tabular}{|c|c|c|c|c|c|c|c|}
\hline & \multirow[b]{2}{*}{ Class } & \multicolumn{3}{|c|}{ Kolmogorov-Smirnov $^{\mathrm{a}}$} & \multicolumn{2}{|c|}{ Shapiro-Wilk } & \multirow[b]{2}{*}{ Sig. } \\
\hline & & Statistic & $\mathrm{df}$ & Sig. & Statistic & $\mathrm{df}$ & \\
\hline \multirow{4}{*}{$\begin{array}{l}\text { Critical } \\
\text { Thinking }\end{array}$} & PreTest Experiment & .141 & 40 & .045 & .939 & 40 & .031 \\
\hline & PostTest Experiment & .113 & 40 & $.200^{*}$ & .958 & 40 & .143 \\
\hline & PreTest Control & .095 & 38 & $.200^{*}$ & .958 & 38 & .161 \\
\hline & PostTest Control & .130 & 38 & .103 & .939 & 38 & .040 \\
\hline
\end{tabular}


analysis by Kolmogof Smirnov. The (2-tailed) experimental group showed that the pretest was 0.141 and the post-test was 0.200 . The next is the control class with pre-tests is 0.095 and a post-test of 0.130 .

Furthermore, homogeneity test to show the diversity in the two subject groups. The homogeneity test uses Levene's test at the $95 \%$ significance level.

Table 9

Homogeneity of variance test

\begin{tabular}{llllll}
\hline & & Levene Statistic & df1 & df2 & Sig. \\
\hline Critical & Mean & 1.252 & 1 & 76 & .267 \\
\cline { 2 - 6 } Thinking & Median & 1.029 & 1 & 76 & .314 \\
\cline { 2 - 6 } & Median and with adjusted df & 1.029 & 1 & 64.289 & .314 \\
\cline { 2 - 6 } & Based on trimmed mean & 1.133 & 1 & 76 & .291 \\
\hline
\end{tabular}

The Levene test for the homogeneity test in the table below states the probability result (sig.) $\geq 0.05$. So, H0 is rejected. In conclusion, the level of critical thinking of the two classes has homogeneous diversity.

\section{Hypothesis Testing}

The hypothesis test aims to decide whether to accept or reject a hypothesis. Hypothesis testing has a significant level of 0.05 (Independent Sample t-Test). Hypothesis testing aims to provide knowledge about the effect of the SPBL model on improving the critical thinking skills of Geography students. The conditions for making this hypothetical decision are as follows:

$\mathrm{H} 1$ = students who apply the SPBL model during the learning process get a higher score of critical thinking skills than those who do not.

$\mathrm{H} 0=$ students who apply the SPBL model during the learning process did not get a higher score of critical thinking skills than those who do not.

Table 10

Group statistic

\begin{tabular}{llllll}
\hline \multicolumn{1}{c}{ Class } & $\mathrm{N}$ & Mean & Std.Deviation & Std.Error Mean \\
\hline Critical & Experiement Post-test & 40 & 73.95 & 7.268 & 1.149 \\
\cline { 2 - 6 } $\begin{array}{l}\text { Thinking } \\
\text { Results }\end{array}$ & Control post-test & 38 & 63.21 & 9.450 & 1.533 \\
\hline
\end{tabular}

From the results of data acquisition after treatment, both groups showed a significant mean value. This shows that the SPBL model provides an increase in students' critical thinking skills. 
Table 11

Independent sample t-test

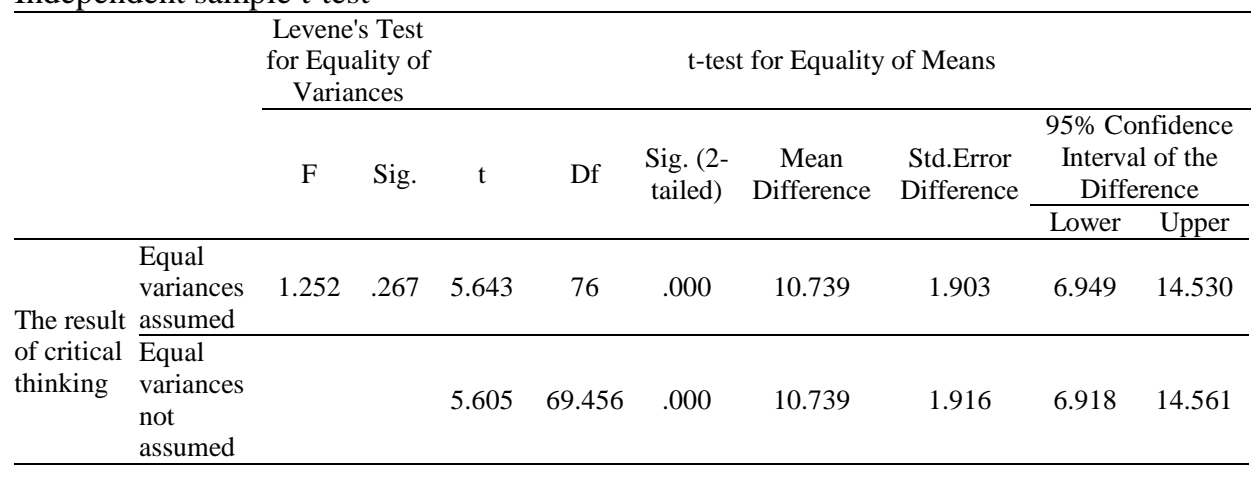

The results of statistical analysis stated that the hypothesis testing was 0.000 for sig (2tailed). Thus, the probability value is $0.000 \leq 0.05$ and the mean value of students' critical thinking after the post-test in the experimental class is (74)> complete class (63). This means that $\mathrm{H} 0$ is rejected.

\section{Experimental and Control Class Critical Thinking Skills}

Table 12 contains information about the acquisition of data from the pre and post-test scores in the experimental and control classes, then the preparation of the frequency distribution of students' critical thinking with the table.

Table 12

The Frequency Distribution of The Pre and Post-Test Data for the Experimental and Control Classes

\begin{tabular}{lllcc}
\hline Qualification & $\begin{array}{l}\text { Pre-test Frequence } \\
\text { Experimental } \\
\text { Class }\end{array}$ & $\begin{array}{l}\text { Post-test frequence } \\
\text { Experimental Class }\end{array}$ & $\begin{array}{l}\text { Pre-test } \\
\text { Frequence } \\
\text { Control Class }\end{array}$ & $\begin{array}{l}\text { Post-test } \\
\text { frequence } \\
\text { Control Class }\end{array}$ \\
\hline Highly critical & 0 & 10 & 0 & 0 \\
\hline Critical & 14 & 24 & 12 & 14 \\
\hline Critical enough & 18 & 6 & 15 & 18 \\
\hline Less critical & 6 & 0 & 9 & 0 \\
\hline Not critical & 2 & 0 & 2 & 0 \\
\hline
\end{tabular}

The table contains information about increasing critical thinking in both subject groups. The experimental group showed an increase in the value of critical thinking compared to the control group. The post-test results showed that most students in the experimental group could think critically. Thus, critical thinking scores changed significantly in the experiment class. the frequency distribution for the experimental class can be illustrated in the following graph. 


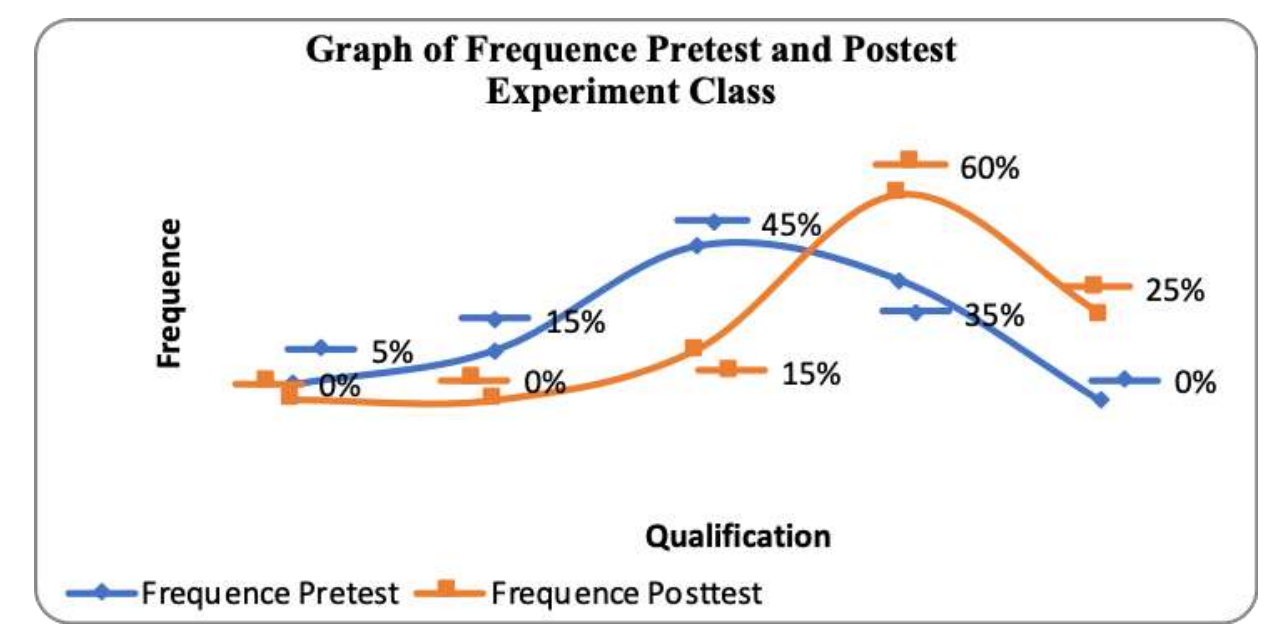

Figure 2

Comparison of Pre-Test and Post-Test Results in Experiment group in Graph

The graph above provides information about increasing scores in the experimental group after treatment. The qualification critical score of the pre-test was $35 \%$, while the posttest was $60 \%$. Qualification score was quite critical at the pre-test by $45 \%$ and $15 \%$ at the post-test. Highly critical score qualification at the post-test was higher by $25 \%$ and $0 \%$ at the pre-test. In the pre-test, $15 \%$ and $0 \%$ in the post-test, there is a qualifying score that is less critical. Then, the percentage difference between the control groups is depicted in the graph below.

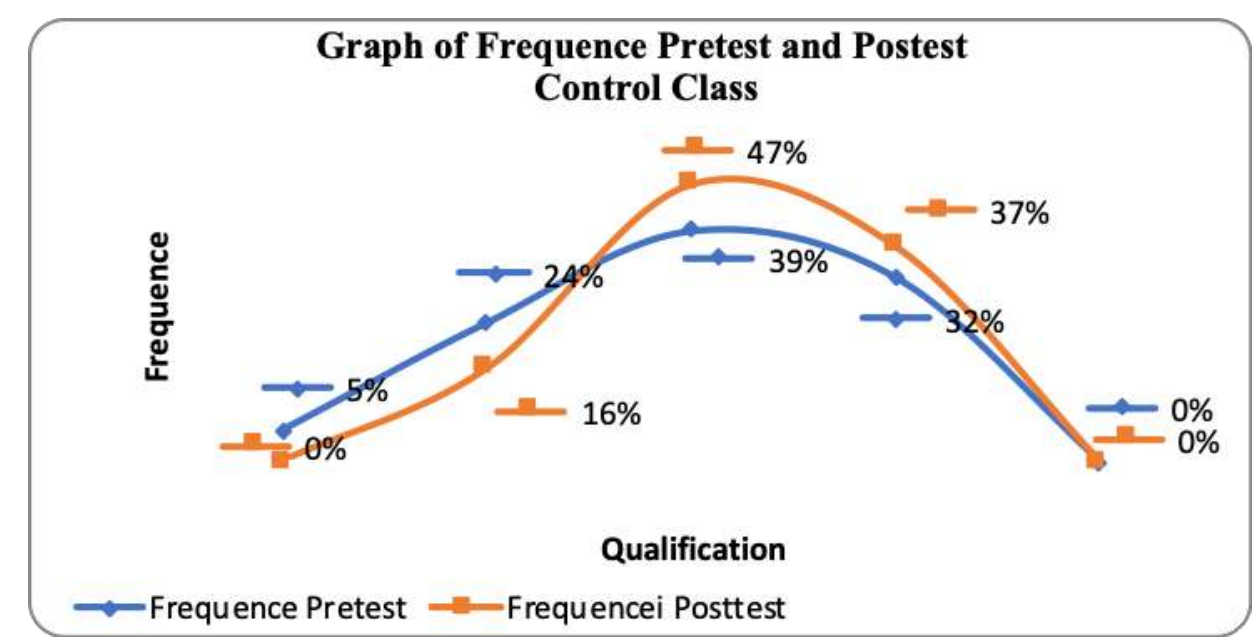

Figure 3

Comparison of the results of the control class pre-test and post-test in a graph 
The graphs describe that there is no "quite critical" score at the pre-test of 39\% and $47 \%$ at the post-test. Qualification of the critical score at the post-test was higher at 37\% and $32 \%$ at the pre-test. Qualification was less critical at the pre-test by $24 \%$ and $16 \%$ at the pre-test. The not critical score is 5\% on the initial test and the post-test is $0 \%$.

From the discussion of these data, it was concluded that the SPBL model improved students' critical thinking skills. However, other findings can provide a new perspective for the SPBL model. The results of the calculation of the N-Gain Score, the SPBL model is not yet effective. This is evidenced from the results of the analysis using SPSS version 23 for windows. A summary of the calculations can be seen in the table below.

Table 13

Summary of N-Gain Score Calculation

\begin{tabular}{llllll}
\hline & Class & & Statistic & Std. Error & Percentage \\
\hline \multirow{2}{*}{ NGain_Percent } & Experiment & Mean & 31.8434 & 1.90395 & $31.8 \%$ \\
\cline { 3 - 5 } & & Minimum & 7.69 & \\
\cline { 2 - 5 } & & Maximum & 58.14 & \\
\cline { 2 - 5 } & \multirow{2}{*}{ Control } & Mean & 5.5804 & 2.84319 & $5.5 \%$ \\
\cline { 3 - 5 } & & Minimum & -37.04 & \\
\cline { 3 - 5 } & & Maximum & 47.83 & \\
\hline
\end{tabular}

Based on the provisions of the experimental effectiveness of a product if it has a percentage value $>76 \%$, it is quite effective when it has a percentage of $56-75 \%$, less effective if it is $40-55 \%$, and is declared ineffective when it is <40\% (Hake, R. R, 1999). The effectiveness of the SPBL model in the experimental class $<40 \%$ is $31.8 \%$. This finding is evidence, although SPBL affects improving students' critical thinking, the SPBL model cannot be declared effective. Meanwhile, to improve students' critical thinking, conventional methods such as lectures applied to control classes are no longer recommended.

\section{DISCUSSION}

Previous research supports the argument that the application of the scientific learning model is superior to conventional learning with the lecture method (Aliman et al., 2019; Farah et al., 2018; Handoyo et al., 2016; Sari et al., 2019; Sumarmi et al., 2019; Sumarmi et al., 2019; Sumarmi et al., 2019; Sumarmi et al. Al., 2020; Aliman et al., 2020; Umiyaroh, 2017). Interactive learning affects the improvement of students' critical thinking (Utami et al., 2016). Acquisition of student knowledge directly from student searches and experiences (Puspitasari et al., 2016) from the scientific learning process (El Bedawy, 2017; Erikson \& Erikson, 2019; Syaodih et al., 2019; Woa et al., 2018).

The results of field observations show that the SPBL syntax is based on their experience, students work together to investigate scientifically to collect data, organize data and analyze data with a spatial approach (Silviariza \& Handoyo, 2020). The scientific syntax can encourage critical thinking (Halim \& Mohtar, 2015; Shaughnessy et al., 2017). Thus, the implementation of the SPBL model provides students with a scientific learning experience in solving critical problems spatially. The implementation 
of the SPBL model helps students solve problems based on a spatial perspective. As is well known, problem-solving based on a spatial point of view is a characteristic of Geography (Goodchild et al., 2007; Huynh, 2009; Miller, 2000; Shoorcheh, 2019).

The research at the first meeting was carried out by pre-test, three meetings took place as usual with the topic of learning "Human Resources with Environmental Insights" and one last meeting took place by carrying out a post-test. Each meeting has a time of 100 minutes.

The first meeting in the experimental class (pre-test) took place on November 14, 2019. The second meeting took place on November 21, 2019. The third meeting took place on November 28, 2019. The fourth meeting took place on December 5, 2019. The last meeting (post-test) was held on 12 December 2019.

The process of learning is oriented towards environmental problems by looking at the spatial pattern (Marshall, et al, 2011). The spatial-based orientation of environmental problems is used with the activity sheet guide. The syntax of the PBL model is adjusted to the student activity sheets. Students are given a stimulus to ask questions and begin to identify some problems. The critical thinking process emerges at this stage. (Paul, \& Elder, 1990). This is based on a learning strategy by providing opportunities for students to think critically (Bonie \& Potts in Amri, 2012).

Class $\mathrm{K}$ as the experimental group with the SPBL model has a higher thinking ability than the control group which is a class A student. Thus, with the results of experimental research in the form of statistical data calculations. In conclusion, there is an effect of the SPBL model treatment on the increase in critical thinking of Geography students.

The control group with conventional treatment did not show a significant increase in critical thinking. In literature class, students are dominant as listeners by relying on subject matter from the teacher so that they are less literate (passive). Teachers are considered the main source of information and knowledge in solving problems (Marmah, 2014). Students are reluctant to look for sources of information directly in the field.

When conducting group discussions in the control class, most students presented arguments that were not based on data. This proves that students' critical thinking is not optimal (Ennis, 2011). Also, some students were not enthusiastic about participating in the discussion. Researchers assume that this is due to lessons that take place during the day after recess.

Another thing with the experimental group treatment with SPBL, students were able to identify problems from a spatial perspective, orient problems spatially, formulate problems, collect and compile data and information spatially, analyze data and information spatially together and communicate scientifically about the results of problem-solving in front of other groups by way of presentation using power points in front of the class. The process of solving spatial problems takes place scientifically (Silviariza, et al, 2020). 
In infield activities in the experimental class, students are not only actively looking for supporting sources of information in the library, but the information search process is also carried out with other media such as print, mass, and electronic media. The process of arguing confirmation through the search process enabled students to think critically (Ennis, 2011). Furthermore, SPBL effects and is proven by the results of the post-test. So, the conclusion is that during the treatment process the SPBL model can improve critical thinking shown by test results and student behavior. The steps in the SPBL model allow students to become centers of learning. Besides, student learning activities are constructive.

\section{CONCLUSION}

The SPBL model provides a reference for teachers to improve critical thinking in solving geographic problems. Learn directly with spatial problems can maintain geographic scientific ethics in school learning. It is proven from the experimental results that the SPBL model has a significant effect on students' critical thinking skills. The control class and the experimental class for the pre-test and post-test with a significant score $<0.05$. The difference in the mean score between the two groups is the reason for the conclusion.

In addition to proving the hypothesis, the finding of an N-Gain score $<40 \%$ is certainly an important thing to pay attention to. Although the SPBL model enhances students' critical thinking, the SPBL model product needs further evaluation so that its effectiveness and quality are getting better.

\section{REFERENCES}

Affandy, H.; Aminah, N. S.; \& Supriyanto, A. (2019, February). The correlation of character education with critical thinking skills is an important attribute to success in the 21st century. In Journal of Physics: Conference Series, 1153(1), 012132. IOP Publishing.

Aliman, M.; Budijanto; Sumarmi; \& Astina, I. K. (2019). Improving Environmental Awareness of High School Students' in Malang City through Earthcomm Learning in the Geography Class. International Journal of Instruction, 12(4), 79-94. https://doi.org/10.29333/iji.2019.1246a

Aliman, M.; Mutia, T.; Halek, D. H.; Hasanah, R.; \& Muhammad, H. H. (2020). Pengembangan Instrumen Tes Kemampuan Berpikir Spasial Bagi Siswa SMA [Development of Spatial Thinking Ability Test Instruments for High School Students]. Geodika: Jurnal Kajian Ilmu dan Pendidikan Geografi, 4(1), 10. https://doi.org/10.29408/geodika.v4i1.1823

Ali Ismail, H. A.; McGuire, P. (2015). 21st century standards and curriculum: Current research and practice. Journal of Education and Practice, 6(6), 150-154.

AlJaafi, E.; Şahin, M. (2019). Critical Thinking Skills For Primary Education: The Case In Lebanon. Turquoise International Journal of Educational Research and Social Studies, 1(1), 1-7. 
American Management Association. (2010). AMA Critical Skills Survey: Workers Need Higher Level Skills to Succeed in the 21st Century. https://www.amanet.org//articles/ama-critical-skills-survey-workers-need-higher-levelskills-to-succeed-in-the-21st-century/

Arikunto, S. (2010). Prosedur Penelitian [Research Procedure]. PT. Rineka Cipta, Jakarta.

Bedawy, R. E. (2017). Experiential Learning for Supporting Learning Effectiveness in Business Education: A Case Study from Egypt. International Journal of Business and Management, 12(5), 159. https://doi.org/10.5539/ijbm.v12n5p159

Bednarz, R. \& Bednarz, S. (2008). The Importance of Spatial Thinking in an Uncertain World. D.Z. Sui (ed.) Geospatial Technologies and Homeland Security. 10.1007/978-14020-8507-9_16.

Campbell, D. T., \& Stanley, J. C. (2015). Experimental and quasi-experimental designs for research. Ravenio Books

Casner-Lotto, J.; Barrington, L. (2006). Are they ready to work? Employers' perspectives on the basic knowledge and applied skills of new entrants to the 21st century US workforce. Partnership for 21st Century Skills. 1 Massachusetts Avenue NW Suite 700, Washington, DC 20001.

Chun, B. A. 2010. Effect of GIS-integrated Lessons on Spatial Thinking Abilities and Geographical Skills. Journal of the Korean Geographical Society, 45(6), 820-844.

Conklin, W. 2012. Higher- Order Thinking Skills to Develop 21st Century Learner. Huntington Beach, United States of America: Shell Education Publishing Inc.

Darmaji, D.; Kurniawan, D. A.; Irdianti, I. (2019). Physics Education Students' Science Process Skills. International Journal of Evaluation and Research in Education, 8(2), 293-298.

Elbow, G. S., \& Sharma, M. B. (2000). Using Internet Primary Sources to Teach Critical Thinking Skills in Geography. Libraries Unlimited.

Ennis, R. H. (2011). The Nature of Critical Thinking: An Outline of Critical Thinking Dispositions and Abilities. Online. Available in http://faculty.education.illinois.edu/rhennis/documents/TheNatureofCriticalThinking_51 711_000.pdf. Accessed 9-03-2019

Erikson, M. G., \& Erikson, M. (2019). Outcomes and Critical Thinking-Good Intentions in Conflict Learning. Studies in Higher Education, 44(12), 2293-2303. https://doi.org/10.1080/03075079.2018.14868133

Facione, P. A. (2000). The Disposition Toward Critical Thinking: Its Character, Measurement, and Relationship to Critical Thinking Skills. Informal Logic, 20(1). https://doi.org/10.22329/il.v20i1.2254 
Facione, P. A. (2011). Critical Thinking: What It Is and Why It Counts. Millbrae: Measured Reasons and The California Academic Press

Farah, F. A.; Handoyo, B.; \& Bachri, S. (2018). Pengaruh Model Problem Based Learning terhadap Keterampilan Geografi [The Influence of the Problem Based Learning Model on Geography Skills]. Jurnal Pendidikan: Teori, Penelitian, dan Pengembangan, 3(10), 1391-1397. https://doi.org/10.17977/jptpp.v3i10.11738

Fatmawati, Z. A.; Susilowati, S. M. E.; Iswari, R. S. (2019). Effect of Argument-Driven Inquiry (ADI) with a problem-solving method for student's argumentation and critical thinking skills. Journal of Innovative Science Education, 8(3), 255-263.

Fraenkel, J. R.; Wallen, N. E.; Hyun, H. H. (2011). How to design and evaluate research in education. New York: McGraw-Hill Humanities/Social Sciences/Languages.

Goodchild, M. F.; Yuan, M.; \& Cova, T. J. (2007). Towards a general theory of geographic representation in GIS. International Journal of Geographical Information Science, 21(3), 239-260. https://doi.org/10.1080/13658810600965271

Hake, R.R. 1999. Analyzing Change/Gain Scores. Dept. of Physics Indiana University. Downloaded from http://www.physics.indiana.edu on 24-03-2021.

Halim, L., \& Mohtar, L. (2015, November 19). Critical Thinking Process in Science Learning.

Handoyo, B.; Amirudin, A.; \& Soekamto, H. (2016). Analyzing The Geographical Skills Across The World Secondary Schools Curriculum Based on The Scientific Approach. Atlantis Press. https://www.atlantis-press.com/proceedings/icge-16/25875234

Haridza, R., Irving, K.E. (2017). Developing Critical Thinking of Middle School Students using Problem Based Learning 4 Core Areas (PBL4C) Model. Journal of Physics: $\quad$ Conference Series. DOI:10.1088/1742-6596/812/1/012081. https://doi.org/10.1088/1742-6596/812/1/012081

Huang, K. H.; Hung, K.-C.; Cheng, C.-C.; \& Cheng, C.-C. (2012). Enhancing Interactivity in Geography Class: Fostering Critical Thinking Skills through Technology. Problems of Education in the 21st Century, 50.

Huynh, N. (2009). The Role of Geospatial Thinking and Geographic Skills in Effective Problem Solving with GIS: K-16 Education. Theses and Dissertations (Comprehensive).

Jones, C., \& Pimdee, P. (2017). Innovative ideas: Thailand 4.0 and the fourth industrial revolution. Asian International Journal of Social Sciences, 17, 4-35. https://doi.org/10.29139/aijss.20170101

Karakoç, M. C. (2016). The Significance of Critical Thinking Ability in terms of Education. Ipaper/The-Significance-of-Critical-Thinking-Ability-in-ofKarako\%C3\%A7/8456db20169266fb23758413dfcf5a11aa4b3c67 
Kereluik, K.; Punya. M.; Chris. F.; \& Laura, T. (2013). What Knowledge Is of Most Worth. Journal of Digital Learning in Teacher Education. 29. 127-140. 10.1080/21532974.2013.10784716.

Koohang, A.; Riley, L.; Smith, T. J.; \& Schreurs, J. (n.d.). E-Learning and Constructivism: From Theory to Application. Interdisciplinary Journal of E-Skills and Lifelong Learning, 5, 091-109.

Kraisuth, D., \& Panjakajornsak, V. (2017). Thai engineer ASEAN readiness: A structural equation model analysis. Asia-Pacific Social Science Review, 16, 96-117.

Lai, E. R. (2011). Critical thinking: a Literature review. Author, Pearson Assessments.

http://www.pearsonassessments.com/hai/images/tmrs/CriticalThinking

Loveless, A.; Burton, J.; \& Turvey, K. (2006). Developing conceptual frameworks for creativity, ICT, and teacher education. Thinking Skills and Creativity, 1(1), 3-13. https://doi.org/10.1016/j.tsc.2005.07.001

Marshall, P., Rogers, Y., \& Pantidi, N. (2011, March). Using F-formations to analyze spatial patterns of interaction in physical environments. In Proceedings of the ACM 2011 conference on Computer supported cooperative work, 445-454.

Miller, H. J. (2000). Geographic Representation in Spatial Analysis. Journal of Geographical Systems, 2(1), 55-60. https://doi.org/10.1007/s101090050030

Nagel, P. (2008). Geography: The Essential Skill for the 21st Century. Social Education, 72(7), 354

Nappi, J. S. (2017). The importance of questioning in developing critical thinking skills. Delta Kappa Gamma Bulletin, 84(1), 30.

National Association of Colleges and Employers. (2016). Believes It is "Carrer Ready", but is It? http://tinyurl.com/ya8a559g

Nelson, A. C. (2013). Impact of critical thinking on performance in mathematics among senior secondary school students in Lagos state. IOSR Journal of Research \& Method in Education (IOSR-JRME), 3(3), 18-25

Nursa'ban, M.; Kumaidi, K.; Mukminan, M. (2020). Factors of critical spatial thinking for a geography metacognition assessment in Indonesian Senior High Schools. Review of International Geographical Education Online (RIGEO), 10(2), 186.

Papathanasiou, I. V.; Kleisiaris, C. F.; Fradelos, E. C.; Kakou, K..; \& Kourkouta, L. (2014). Critical Thinking: The Development of an Essential Skill for Nursing Students. Acta Informatica Medica, 22(4), 283-286. https://doi.org/10.5455/aim.2014.22.283-286 Partnership for 21st Century Skills (P21). (2015). Framework for 21st-century learning.

Retrieved from P21 Partnership for 21st Century Skills: http://www.p21.org/ourwork/p21-framework. 
Paul, R., \& Elder, L. (2019). Critical Thinking: Tools for Taking Charge of Your Learning and Your Life (3 edition). Pearson.

Paul, R.; Elder, L. (1990). Critical thinking. Rohnert Park, CA: Sonoma State University

Pérez-delHoyo, R.; Mora, H.; Martí-Ciriquián, P.; Pertegal-Felices, M. L.; Mollá-Sirvent, R. (2020). Introducing innovative technologies in higher education: An experience in using geographic information systems for the teaching-learning process. Computer Applications in Engineering Education, 28(5), 1110-1127

Purwanto, E. (2012). Pengembangan Modul [Module Development]. Depdiknas.

Purwanto. (2009). Evaluasi hasil belajar [Evaluation of learning outcomes]. Pustaka Pelajar.

Puspitasari, E.; Sumarmi; \& Amirudin, A. (2016). Integritas Berpikir Kritis Dan Peduli Lingkungan Melalui Pembelajaran Geografi Dalam Membentuk Karakter Peserta Didik SMA [Integrity of Critical Thinking and Care for the Environment through Geography Learning in Forming the Character of High School Students]. Jurnal Pendidikan: Teori, Penelitian, dan Pengembangan, 1(2), 122-126.

Rahmat, N. H.; Aripin, N.; Lin, N. M.; Whanchit, W.; Khairuddin, Z. (2020). Exploring the Connection between Critical Thinking Skills and Academic Writing. International Journal of Asian Social Science, 10(2), 118-128.

Saputra, M. D.; Joyoatmojo, S.; Wardani, D. K..; Sangka, K. B. (2019). Developing Critical-Thinking Skills through the Collaboration of Jigsaw Model with Problem-Based Learning Model. International Journal of Instruction, 12(1), 1077-1094.

Saputri, A. C.; Sajidan; Rinanto, Y.; Afandi; \& Prasetyanti, N. M. (2019). Improving

Students' Critical Thinking Skills in Cell-Metabolism Learning Using Stimulating Higher Order Thinking Skills Model. International Journal of Instruction, 12(1), 327342. https://doi.org/10.29333/iji.2019.12122a.

Sari, R. M.; Sumarmi; Astina, I. K.; Utomo, D. H.; \& Ridhwan, R. (2019). Measuring Students Scientific Learning Perception and Critical Thinking Skills Using Paper-Based Testing: School and Gender Differences. International Journal of Emerging Technologies in Learning (IJET), 14(19), 132-149.

Shaughnessy, M. F.; Varela, M.; \& Liu, Z. (2017). Critical Thinking in Science: What Are the Basics? World Journal of Educational Research, 4(4), 585. https://doi.org/10.22158/wjer.v4n4p585

Shoorcheh, M. (2019). On the Spatiality of Geographic Knowledge. Asian Geographer, 36(1), 63-80. https://doi.org/10.1080/10225706.2018.1463854

Silviariza, W. Y., \& Handoyo, B. (2020). Spatial-Problem Based Learning (SPBL) Development (Preliminary Studies for Geography Learning). Jurnal Pendidikan 
Geografi: Kajian, Teori, Dan Praktek Dalam Bidang Pendidikan Dan Ilmu Geografi, 25(1), 69-79.

Snyder, L. G., \& Snyder, M. J. (2008). Teaching Critical Thinking and Problem Solving Skills. Delta Pi Epsilon Journal, 50(2), 90-99.

Suardana, I. N.; Selamat, I. N. (2012). Analisis Keterampilan Berpikir Kritis Siswa SMA di Kabupaten Buleleng [Analysis of Critical Thinking Skills of High School Students in Buleleng Regency]. In Prosiding Seminar Nasional MIPA.

Sulaiman, W. S. W.; Rahman, W. R. A.; \& Dzulkifli, M. A. (2008). Relationship Between Critical Thinking Dispositions, Perceptions Towards Teacher, Learning Approaches, and Critical Thinking Skills Among University Students. The Journal of Behavioral Science, 3(1), 122-133.

Sumarmi. (2012). Model-Model Pembelajaran Geografi [Geography Learning Models]. Malang: Aditya Media Publishing.

Sumarmi. (2017). Influence of local wisdom-based blended learning module for environmental geography towards problem-solving skills. Advances in Social Science, Education and Humanities Research, 164, 157-160. https://doi.org/10.2991/icli17.2018.30.

Sumarmi; Bachri, S.; Listyo Y. I.; Putra, D. B. P; Risnani; \& Aliman, M. (2020). The Effect of Experiential Learning Models on High School Students Learning Scores and Disaster Countermeasures Education Abilities. Journal for the Education of Gifted Young Scientists, 8(1), 61-85. https://doi.org/10.17478/jegys.635632

Sun, Z.; Lin, C. H.; Wu, M.; Zhou, J.; Luo, L. (2018). A tale of two communication tools: Discussion-forum and mobile instant-messaging apps in collaborative learning. British Journal of Educational Technology, 49(2), 248-261.

Swan, K. (2005). A Constructivist Model for Thinking About Learning Online. Elements of Quality Online Education: Engaging Communities, 6, 1-19.

Syaodih, E.; Suhandi, A.; Maftuh, B.; Hermita, N.; Fratiwi, N. J.; \& Samsudin, A. (2019). Development and Implementation of Creative, Solutive, and Smart Teaching (CS2T) to Improve 21st Century Capability on Wave and Optics. Journal of Physics: Conference Series, 1280, 052051. https://doi.org/10.1088/1742-6596/1280/5/052051

Tapper, J. (2004). Student Perceptions of How Critical Thinking is Embedded in a Degree Program. Higher Education Research \& Development, 23(2), 199-222. https://doi.org/10.1080/0729436042000206663

Tsui, L. (2002). Fostering Critical Thinking through Effective Pedagogy: Evidence from Four Institutional Case Studies. The Journal of Higher Education, 73(6), 740-763. JSTOR.

Umiyaroh, F. (2017). The Influence Of Double Loop Problem Solving Learning Models to Senior High School Learners Spatial Thinking Ability. /paper/The-Influence-Of 
Double-Loop-Problem-Solving-Models

Umiyaroh/37e0f472f968956048a80a1f6ecb0fa86f87bda9

Utami, W. S.; Sumarmi; Ruja, I. N.; \& Utaya, S. (2016). React (Relating, Experiencing, Applying, Cooperative, Transferring) Strategy to Develop Geography Skills. Journal of Education and Practice, 7(17), 100-104.

Wagner, T. (2010). Overcoming the global achievement gap (online). Cambridge,

Mass., Harvard University.

Wayudi, M.; Suwatno; \& Santoso, B. (2020). Kajian analisis keterampilan berpikir kritis siswa sekolah menengah atas. Jurnal Pendidikan Manajemen Perkantoran

5(1), 67-82. doi: 10.17509/jpm.v4i2.18008. http://ejournal.upi.edu/index.php/jpmanper

Woa, K. M.; Utaya, S.; \& Susilo, S. (2018). Pengaruh Model Pembelajaran Problem Based Learning terhadap Kemampuan Memecahkan Masalah Geografi pada Siswa SMA [The Effect of Problem Based Learning Learning Model on the Ability to Solve Geography Problems in High School Students]. Jurnal Pendidikan: Teori, Penelitian, dan Pengembangan, 3(3), 406-411.

Yanchar, S. C.; Slife, B. D. (2004). Teaching critical thinking by examining assumptions. Teaching of Psychology, 31(2), 85-90.

Yunus, H. S. (2008, January). Konsep dan Pendekatan Geografi, Memakai Hakekat Keilmuan [Geographical Concepts and Approaches, Using Scientific Essence] In Papers presented at the Seminar and Workshop: Substansi dan Kompetensi Geografi [Geographical Substance and Competence]. On January 18-19, 2008, 18, 1-25.

ŽivkoviL, S. (2016). A Model of Critical Thinking as an Important Attribute for Success in the 21st Century. Procedia - Social and Behavioral Sciences, 232, 102-108. https://doi.org/10.1016/j.sbspro.2016.10.034 